\title{
EXPERTS' OPINIONS OF FACTORS AFFECTING SERVICE- RELATED COMMERICAL LAND USE PATTERN: THE CASE OF ALKHOBAR CITY
}

\author{
M. A. Abdellatif ${ }^{*}$, K. M. Maniruzzaman, B. A. Al-Nuaim \\ Department of Urban \& Regional Planning College of Architecture and Planning, University of \\ Dammam, Dammam, Saudi Arabia
}

Received 8 April 2013, accepted 9 May 2013

\begin{abstract}
Due to shortage of local research in Saudi Arabia dealing with land use planning in general and service-related commercial land use in specific, there is a lack of sound understanding among professionals dealing with land use planning, which in turn causes a large disparity in urban structure in the current Saudi cities. The main goal of the study is to determine the factors affecting service-related commercial land use pattern in Alkhobar City, in the Eastern Province of the Kingdom of Saudi Arabia. The study accomplished this aim by conducting a literature review and a field questionnaire survey applied on a sample of planning experts to verify stated hypothesis defining the factors affecting service-related commercial land use pattern. Principle Component Analysis and Regression Analysis were used to define these factors and the level of impact for each foctor. The study found that service-related commercial land use pattern is determined by factors related to the site spatial planning and regulations and strategic issues. These factors include road width, availability of landscape elements, accessibility, mobility, land use regulations, land use mechanism and availability of commercial lands for population.
\end{abstract}

Keywords: Service-related Commercial land use pattern, Urban Development, spatial planning, land ownership, factor analysis, Stepwise Regression Analysis, Alkhobar City, Kingdom of Saudi Arabia

\section{Study background}

The concept of land use (i.e., the way a particular piece of land is utilized by humans and other living organisms), seems simple and straightforward on the surface. Humans use land to build cities where they live (residential land) and work (Commercial land). They use land for growing crops and raising livestock (agricultural land) for food. Forestland provides fuel for energy and lumber for building. Humans use land for play (recreational land) and set some of it aside as exclusive wildlife habitat (wilderness land). But no matter how land is used by humans and other living species, humans ultimately decide how land is used. Given the nature of humans, land use involves a complex interplay of environmental parameters, economic needs and often politics.

Most countries, especially developing countries, are suffering from the increase of urban population as a result of natural increase and the continuing migration of rural people. These factors have led to extend the urban inside and outside cities limits with rates above the levels of urban development. Also, these factors complicate the old city problems and generate new problems such as increasing urban land price, housing shortages, the spread of slum conditions in the city center, the indiscriminate growth outside the city limits, extending construction on parks and open spaces, overlapping land uses, traffic congestion,

\footnotetext{
* Corresponding author.

E-mail address: mlatif@ud.edu.sa
} 
M. A. Abdellatif, et al., Experts' optinions of factore affecting service-related commerical land use pattern: the case of Alkhobar city

lack of services and facilities and generation of social and economic problems, especially unemployment.

Urban morphology is concerned with the study of the built-up area of the city (its layout, form, and function) and the ways in which these elements have evolved over time (Small and Witherick, 1986). Johnson (1972) listed three morphological components of a city; the first is the plan of the streets, which display past and present methods of transportation. A second component is building form, which is more susceptible to gradual change through time. The functions of the streets and buildings constitute a third element in city morphology. An example of this function is the bustle of people on a city's streets and their activities within its buildings. The nature of technology and the whims of fashion are parts of diverse forces which shape the elements of urban morphology (Johnson, 1972). Urban landscape components, such as streets, buildings, gardens, and other open spaces, furnish a demonstration of the city's inner workings and its past (Barnett, 1982).

Saudi Arabian cities in general are suffering from clear urban disparities in their physical compositions because of large diversities in their social elements. This problem seems clear when comparing the number of urban communities within the same city, which reflects many contradictions and inconsistency of each of those communities as well as the whole city.

\subsection{Statement of problem}

Due to a dearth of research in a Saudi Arabian context dealing with factors affecting land use in general and commercial land use in specific, there is a lack of sound understanding among professionals dealing with urban land use planning, producing improper land use plans and resulting in large disparities in urban land use structure in the current Saudi cities. Mixing uses is natural since it follows the law of supply and demand. There are in residential areas daily and continuous needs for some types of services supplying foods, materials and goods (i.e., supermarket, bakery and laundry). The existence of other shops (i.e., carpentry, metal workshops and materials distributors) integrated with housing is not necessary, especially since some of those shops cause nuisance and inconvenience to residents who live near them. We can speculate the reasons that led to this mixing to be the high rents in commercial areas and people's preference to live near their work and shops.

\subsection{Definition of service-related commercial land use pattern}

According to Berke,P., Godschalk, D., Kaiser, E. , Rodríguez, D. (2006)., contemporary land use classification mainly categorizes land use zones in urban areas into three groups: commercial areas, industrial areas and residential areas. Commercial areas are usually classified and allocated to be within easy proximity to both industrial and residential areas. They usually comprise the central business districts of most urban areas and are characterized by business premises, financial services and main markets.

The study develops further the classification according to commercial activities based on Alkhobar's commercial licenses list which reflect the existing distribution of commercial uses within Saudi Arabia. The developed classification contains three categories (Asharqia Chamber, 2011):

Journal of Engineering Sciences, Assiut University, Faculty of Engineering, Vol. 41, No. 3, pp. 1328 - 1351, May, 2013,E-mail address: jes@aun.edu.eg 
M. A. Abdellatif, et al., Experts' optinions of factore affecting service-related commerical land use pattern: the case of Alkhobar city

1. Industry-related commercial activities (sales related to industry) such as wood industry, chemical and metal industries, non-metallic industries, storage and cooling, paper and its products sales, electrical industries.

2. Service-related commercial activities (sales related to services) such as insurance services and warranty, real estate offices, transport of passengers and goods services, transportation services, agricultural services, services relating to trade, services of banks and financial institutions.

3. Commodity-related commercial activities (sales related to consumer goods and commodities) such as wholesale and retail trade, restaurants and hotels, textiles, food sales, oil and gas, tourist agencies, entertainment centres.

In this paper, the commodity-related commercial type "the plain buying and selling services commercial activities" is selected as a research focus within this type. The research studies a mix of commercial strips within Alkhobar City.

\subsection{Research hypothesis}

This study hypothesizes that there is no statistically significant relationship between service-related commercial lands use patterns and specific spatial, demographic, economic and regulatory factors. These factors are the spatial planning of the site; architectural design of the building; population, demography and economy; relation with landlords and business owners and factors related to planning and regulations and strategic planning.

\subsection{Research goal and objectives}

The main goal of the study is to test the above stated hypothesis and as such to build a sound understanding of factors affecting service-related commercial land use pattern in Alkhobar City. This goal will be achieved through the delivery of several operational objectives:

4. To review and compile the findings of previous studies on the subject.

5. To provide a proper and timely profile of the commercial land use pattern in the City of Alkhobar.

6. To develop a sound approach and methodology for data collection, analysis and synthesis.

7. To test the research hypothesis and to investigate the possible interrelationships of commercial land use pattern in Alkhobar City and factors that might be affecting it.

8. To build a better understanding of the studied subject based on the research findings.

\subsection{Research methodology}

This study employs the causal comparative descriptive research approach to describe the existence and nature of certain relationships between socio-economic and physical factors and commercial land uses patterns focusing on six major commercial strips in Alkhobar City. Secondary data was collected through a literature search of previous studies, books,

Journal of Engineering Sciences, Assiut University, Faculty of Engineering, Vol. 41, No. 3, pp. 1328 - 1351, May, 2013,E-mail address: jes@aun.edu.eg 
M. A. Abdellatif, et al., Experts' optinions of factore affecting service-related commerical land use pattern: the case of Alkhobar city

journal articles, etc. The review defines the main terms and concepts of the research such as: land use theory, classification of land use, land use models, and major factors affecting commercial land use pattern. Primary data was collected through a structured questionnaire consisting of five-parts and forty two variables applied on a sample of respondents from among owners, decision makers and planning experts involved in actual planning of the city. Regression Analysis and Factor Analysis techniques were used to explore the significant affecting factors.

\subsection{Study area}

AlKhobar is one of the three main cities in the Eastern Province of the Kingdom of Saudi Arabia (KSA) (the others being Dammam and Dhahran) as shown in Figure 1. These three cities form a closely joined triangle which has existed for centuries. Figure 2 shows Alkhobar City boundary with its five major districts, namely: North Alkhobar, West Alkhobar, South Alkhobar, Rakah and Thoqbah.

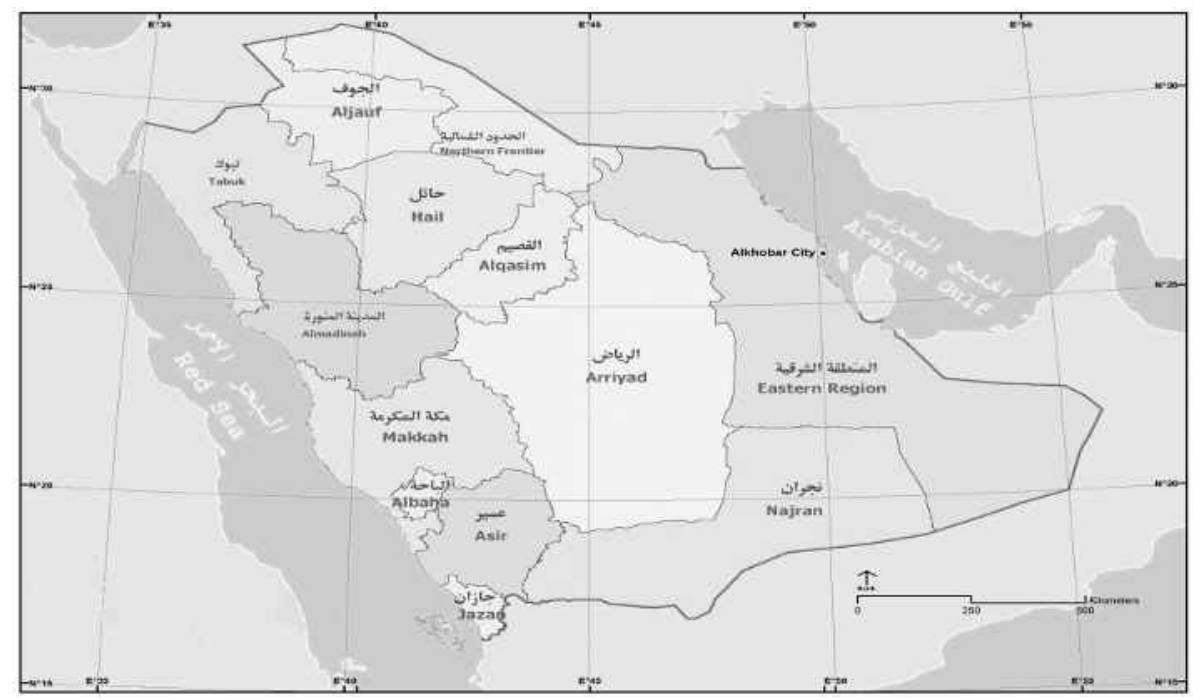

Source: by author based on Central Department of Statistic and Information (2004)

Fig. 1. Location of Alkhobar City

\section{Literature review}

The aim of this section is to identify and describe the various factors that might be affecting commercial land use pattern based on a review of previous studies. These factors are spatial planning of the site, architectural design of the building, demographic and economic characteristics, relation with landlords and business owners' characteristics and factors related to planning, economic and strategic issues.

Journal of Engineering Sciences, Assiut University, Faculty of Engineering, Vol. 41, No. 3, pp. 1328 - 1351, May, 2013, E-mail address: jes@aun.edu.eg 
M. A. Abdellatif, et al., Experts' optinions of factore affecting service-related commerical land use pattern: the case of Alkhobar city

\subsection{Impact of Site spatial planning}

In Alkhobar, the structures are mainly scattered over the commercial zone with most buildings from the times when there was no plan in existence. However, a new order is evidently starting to take shape with new controlled developments slowly replacing old structures and infrastructure. New physical plans for the commercial zones reveal a consideration for a good transport network and open spaces in the city. There are also spaces for expansion and other public utilities like public parks (Friedman et al. 2005).

Utility infrastructures in production and transfer of electricity in the Saudi Arabia cities including Alkhobar always need proper planning and investment. Saudi Arabian cities therefore have to incorporate in their commercial land use plans the need to supply enough power to places where it is needed especially the intensive power consuming sections. Another important factor that determines land use and spatial planning in Saudi Arabia is water supply; most areas in the country including Alkhobar are supplied by an underground aquifer that is running dry with each year of heavy usage. Consequently, most physical planning for commercial places in cites are being planned with water conservation in mind as one of the aforementioned sustainable development strategies, the same is also true for energy. Plans are incorporated in physical planning of urban commercial zones that are aimed at cutting down power usage and wastage for sustainability (Al-Sudairi and Al-Motairi, 2010).

\subsection{Impact of building design factors}

People spend much of their days inside buildings, yet relatively little is known about how the design of buildings or their site influences the physical land use and activities in the surrounding areas. Although some evidence suggests that using specific features of buildings and their immediate surroundings such as stairs can have a meaningful and healthy impact, the influences of the physical environment on physical activity at the building and site scale are not yet clear. While there is some research suggesting that people will be more active in buildings that have visible, accessible, pleasing, and supportive features, such as motivational point-of-decision prompts and well-designed stairs, there is only limited evidence to support that assertion (Am J Prev Med, 2005).

The external form of a building is generally neither emulator nor excludable, and therefore can usually be considered a public good. In fact, there is little doubt that 'good' or 'high quality' architecture is a public good, one that creates positive externalities for the surrounding structures and communities (Bourassa et al., 2004). This concept of quality architecture as a public good explains, in part, the existence of historic districts, design reviews, planning boards, and government imposed aesthetic requirements for permitting.

If there is a positive externality to quality architecture on the surrounding buildings, tenants, and bystanders, then there must exist a 'socially optimal' level of design that may or may not be equal to the optimal level as measured by the private market.

Journal of Engineering Sciences, Assiut University, Faculty of Engineering, Vol. 41, No. 3, pp. 1328 - 1351, May, 2013,E-mail address: jes@aun.edu.eg 
M. A. Abdellatif, et al., Experts' optinions of factore affecting service-related commerical land use pattern: the case of Alkhobar city

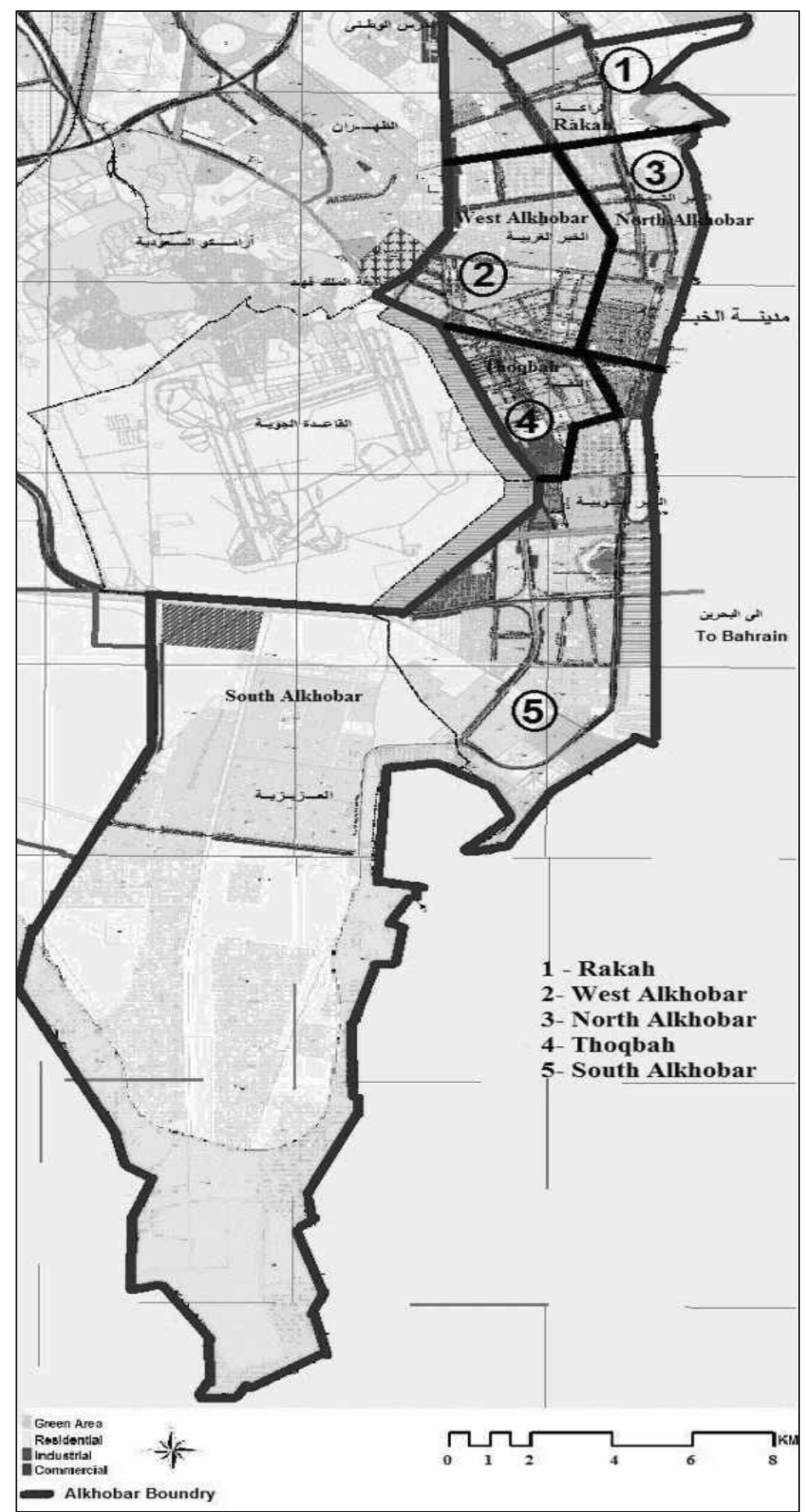

Source: by author based on Dammam Metropolitan Structure Plan (2006)

Fig. 2. Major Districts in Alkhobar City

Journal of Engineering Sciences, Assiut University, Faculty of Engineering, Vol. 41, No. 3, pp. 1328 - 1351, May, 2013, E-mail address: jes@aun.edu.eg 
M. A. Abdellatif, et al., Experts' optinions of factore affecting service-related commerical land use pattern: the case of Alkhobar city

\subsection{Impact of demographic and socio-economic factors}

In many ways, commercial land use is heavily influenced by economics and demographics of any country; this is true for Saudi Arabian cities including Alkhobar (Dammam Municipality, 2007). Most land use models have applied economic theory in their frameworks depending on spatial interactions within the cities. Spatial interaction models are used in determining the nature of migration and spatial land use by the population. Most geographers dealing with land use in the late 19th and early 20th centuries linked spatial interactions with Newton's gravity theory and described migration of people in line with the theory. It was generally assumed that the interaction between two entities was dependent upon their respective sizes and the distance between them. These models have been applied heavily in planning of Saudi Arabian cities including Alkhobar (Alshuwaikhat and Airm, 2006).

Basically, some planners like Huff in 1964 attempted to link the gravity model with basic economic principles on the ground like population and economics and the inherent desire of people to derive maximum utility from a situation. It can seriously be argued that in Saudi Arabia, Alkhobar included, many spatial land use functions are determined by the competition for space within the commercial zone of the city with the planners aiming to maximize the utility of the allocated space as a whole by developing competitive plans for each small space. In applying the micro-economic theory of consumer behaviour, an optimal allocation of specific plots or spaces to people within the commercial area is heavily dependent upon principles of demand and supply (Alshuwaikhat and Airm, 2006). Postulating a utility function reflecting the relative preferences of people at the commercial zone of particular attributes is common. Many times spaces will be allocated within the commercial zone with particular attributes meant for certain types of activity, the people are then drawn to the different spaces by attributes that they find desirable and affordable to them. This approach is heavily based on the description of individual consumer behaviour which influences their choice of space; this consumer behaviour is heavily influenced by their economic status. Thus many people in Saudi Arabian commercial zones in urban areas will choose areas of the market where they not only can afford or develop but also where they think they will receive maximum utility from their investment (Quest Economic Database, 2008). Thus we have different levels of quality space within the area that can fit the economic profile of all occupants, ranging from high end commercial areas to areas with basic markets and cheaper housing.

\subsection{Impact of land values and ownership factors}

Land use in Saudi Arabian cities including Alkhobar is still heavily influenced by land ownership in many parts of cities and towns including commercial zones. There is a high percentage of land and houses which are still in the ownership and control of individual families since the older days and irrespective of change in land use patterns and control of development, the owners still yield great influence on the kind of land use that can take place in the areas with their interests and they are protected by law. This influences the type of housing present and some other factors like sizes of transport infrastructure and layout of water infrastructure (Mustapha et al. 2010).

Ownership rights and laws determine what city planners and designers can do regarding building setback distances, block heights, distance between properties and other attributes of commercial neighbourhoods. The owners' rights are respected including their lifestyle by laws which do not require the planners and designers to decide the property designs.

Journal of Engineering Sciences, Assiut University, Faculty of Engineering, Vol. 41, No. 3, pp. 1328 -1351, May, 2013,E-mail address: jes@aun.edu.eg 
M. A. Abdellatif, et al., Experts' optinions of factore affecting service-related commerical land use pattern: the case of Alkhobar city

Such designs are determined by local traditions and lifestyles and on a great part religion in the case of Saudi Arabia. It is evident that many buildings and other forms of land use in the commercial areas are heavily influenced by religious considerations and long-time cultural and social traditions passed down over the years (Al-Saud, 2010).

\subsection{Impact of planning policies factors}

Saudi Arabian cities including Alkhobar lacks a comprehensive and integrated land use policy meaning that the existing ones do not adequately cover matters relating to land use. Despite having some policies in place, there is poor coordination among the different government agencies responsible for physical and urban planning, development, as well as environmental conservation. Generally, government agencies do not involve the public in the formulation of land-use policies. This lack of public participation in this crucial planning process hinders the formulation of policies that are socially acceptable and sustainable-development oriented. This poorly coordinated land planning in Saudi Arabia results in imbalances among the various land use types.

The government, however, has put in place policies for the sustainable use of land, influenced by the meagre habitable land resources in the country. Saudi Arabia is one of the countries that have adopted the concept of sustainable development. As such, the country yearns for the development and implementation of an approach that will ultimately lead to sustainable development. In recognition of this fact, emphasis is placed on planning and managing land-use efficiently in order to achieve sustainable development. The Saudi Arabian government has realized and appreciated the fact that land use planning policies and practices play a critical role in the achievement of sustainable development. For instance, structured planning prevents depletion of natural resources and damage to the environment while offering guidelines for physical development. In Saudi Arabian cities including Alkhobar, the fundamental concepts employed in planning, with an aim of achieving sustainable development, include the use of environmental impact assessment for appraisal of individual projects, and strategic environmental impact assessment in the evaluation of policies, plans, and programs (Al-Shihri and Benson, 2002). The concerned ministry and departments have integrated the principles of sustainable land development into the land planning process through the establishment of a sustainability framework. This framework is base on the General Environmental Code, with a Ministerial Committee on the Environment coordinating environmental assessment of programs and plans before approval. However, these efforts focus more on the national land planning level rather than the municipal level. Importantly, the government's sustainability policy in land planning impact land use by other entities such as commercial ventures.

Largely, commercial land use planning in Saudi Arabian cities including Alkhobar are affected by economic planning and strategy (Al-Kahtani, 2011). Currently the Saudi economy still relies heavily on oil production but the current strategies are aimed towards diversification of the economy further than has already been achieved into a fully industrial and commercial type. The country aims to develop an economy characterized by growing diversification of production and income, to expand and improve the inter-sectoral linkages among other things. Domestically the Saudi government aims to continue with its emphasis on core development goals to raise the standard of living of its citizens. The government has identified enhancement of the private sector as one of its strategies.

These major economic and policy strategies affect all parts of the economy including urban planning and development. The strategies directly inform and affect planning

Journal of Engineering Sciences, Assiut University, Faculty of Engineering, Vol. 41, No. 3, pp. 1328 - 1351, May, 2013,E-mail address: jes@aun.edu.eg 
M. A. Abdellatif, et al., Experts' optinions of factore affecting service-related commerical land use pattern: the case of Alkhobar city

policies at the municipal level because every urban planning strategy has got to be aligned with the national strategy and vision (Al-Saud, 2010). One of the areas that will definitely be affected is the commercial sector, this sector is among those targeted for improvement and enhancement in order to provide alternative sources of livelihood to more citizens and reduce dependency on oil revenue. The government aims to empower businesses both at the local and international level so that its people can earn more from trade, get employment in the sector and expand it continuously to increase the national revenue. As a result it is quite obvious that the commercial zones in classified urban areas will change drastically to accommodate the new changes.

In general, major changes in terms of spatial planning and design are taking place in all Saudi Arabian cities including Alkhobar. This is as a direct result of major shifts in policy and economic strategy of the country.

\subsection{Summary of variables cited in previous studies}

From the literature review, it may be noticed that the majority of previous studies concentrated on describing a single or only a few factors that might be influencing land use. This observation necessitates multi-variable analysis of factors that affect the servicerelated commercial land use pattern. The variables may be classified in five categories as shown in Table 1 based on previous studies.

\section{Table 1.}

Summary of Previous Studies Variables

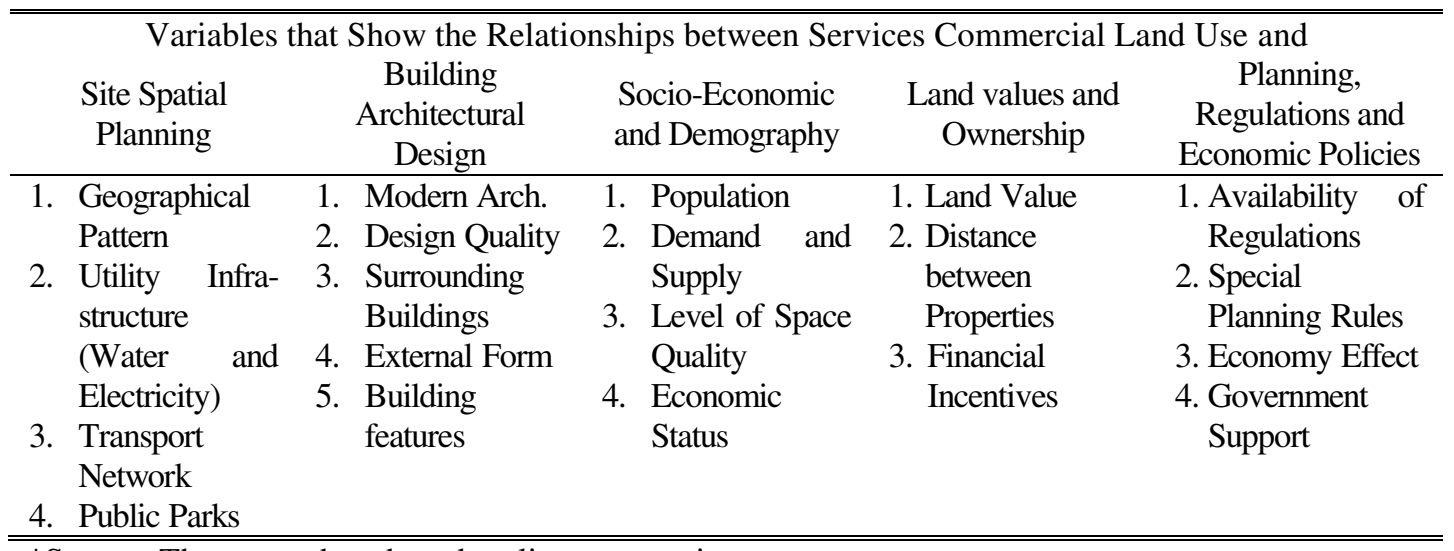

*Source: The researchers based on literature review

\subsection{Developing a comprehensive list of variables}

Starting from the list of variables adopted from previous studies, the researchers have applied several techniques to build a more comprehensive list of variables that might be affecting the commercial land use pattern. Among these techniques is brain storming sessions with experts, city officials and research team members. The list is presented in table 2.

Journal of Engineering Sciences, Assiut University, Faculty of Engineering, Vol. 41, No. 3, pp. 1328 - 1351, May, 2013,E-mail address: jes@aun.edu.eg 
M. A. Abdellatif, et al., Experts' optinions of factore affecting service-related commerical land use pattern: the case of Alkhobar city

\section{Review of commercial land use pattern in Alkhobar city}

In earlier days, Alkhobar was a small port on the Arabian Gulf, a fishing village inhabited mainly by Al Dossary tribe members. With the discovery of oil in the 1930s, it was transformed into a major commercial and shopping center and an industrial port. In modern times, the larger port of Dammam has taken over most commercial shipping activities for the Eastern Province, and oil is exported via the dedicated Saudi Aramco port of Ras Tanura. As a result, Alkhobar has transformed and extended its waterfront along the Gulf into a scenic Beirut-like corniche with parks, eateries, and family beaches, thus making it one of the most iconic features of the city. Moreover, Alkhobar's location along the Arabian Gulf has made it increasingly popular amongst people traveling from cities within the Kingdom. The total area of Alkhobar is around 5,457 hectares and has different uses. Table 3 shows the area of the city by land use class.

\section{Table 3.}

Alkhobar City Land Use Area in Hectare

\begin{tabular}{cccccccc}
\hline \hline Residential and & General & Virgin & Industrial & Agriculture & Roads & Other Uses & Total \\
Commercial & Services & Land & Activities & Activities & & & \\
1239 & 556 & 1721 & 166 & 0 & 1776 & 0 & 5457 \\
\hline \hline
\end{tabular}

Alkhobar has 456,559 residents, which is $13.5 \%$ of the total Eastern Region population based on the $1245 \mathrm{AH}$ (2006 AD) census. The total number of occupied housing in Alkhobar City is 83,237 with a variety of residential patterns include residential neighbourhoods with organic layout, neighbourhoods with a grid layout orthogonal, newly planned neighbourhoods and also closed residential complexes. Generally, Alkhobar is linked to regional road networks and the cities of Dammam and Dhahran by good connections. Alkhobar is linked to Dammam by King Fahd bin Abdul Aziz Road while Prince Faisal bin Fahd and Prince Sultan bin Abdul Aziz Roads link Dhahran to Alkhobar. Also, Alkhobar is linked to Jubail Highway through Dhahran and to south Saudi areas by King Fahd bin Abdul Aziz and King Abdul Aziz Roads. Moreover, Alkhobar is connected to the Kingdom of Bahrain through the Gulf Cooperation Council Road. According to Alkhobar City's approved structure plan (Figure 1), Alkhobar consists of 22 neighbourhoods in five major districts, namely: North Alkhobar, West Alkhobar, South Alkhobar, Rakah and Thoqbah.

\section{Analysis of experts' opinions}

A five-part questionnaire containing 43 variables was developed to explore the factors that may be affecting the attraction and deterrence of services commercial activities to certain locations. In addition to that, fifteen evaluation statements have been added to explore the factors related to policies and strategies. The questionnaire was developed to test the research hypothesis and to determine the relationships between the service-related commercial activities/patterns and factors such as spatial planning of the site, architectural design of the building, demographic and economic characteristics of population, land value and business owners characteristics and planning regulations and economic policies.

Journal of Engineering Sciences, Assiut University, Faculty of Engineering, Vol. 41, No. 3, pp. 1328 -1351, May, 2013,E-mail address: jes@aun.edu.eg 
Table 2 A.

Comprehensive list of variables possibly affecting Service-related Commercial land use pattern

\begin{tabular}{|c|c|c|c|c|}
\hline Site Spatial Planning & $\begin{array}{l}\text { Building Architectural } \\
\text { Design }\end{array}$ & $\begin{array}{l}\text { Socio-Economic and } \\
\text { Demography }\end{array}$ & $\begin{array}{l}\text { Land values and } \\
\text { Ownership }\end{array}$ & $\begin{array}{c}\text { Planning, Regulations and } \\
\text { Economic Policies }\end{array}$ \\
\hline $\begin{array}{l}\text { 1. Grid planning } \\
\text { 2. Horizontal proliferation } \\
\text { 3. Availability } \\
\text { of infrastructure facilities } \\
\text { 4. Location of site in city } \\
\text { outskirts } \\
\text { 5. Location of site in city } \\
\text { center } \\
\text { 6. Availability of Urban } \\
\text { Spaces in the } \\
\text { surrounding area } \\
\text { 7. Availability of green } \\
\text { spaces } \\
\text { 8. Availability of } \\
\text { landscaping elements } \\
\text { 9. Road width } \\
\text { 10. Site accessibility } \\
\text { 11. traffic accessibility on the } \\
\text { surrounding area } \\
\text { 12. Wide sidewalks } \\
\text { 13. Car parking availability } \\
\text { 14. Non-Availability } \\
\text { of tunnels } \\
\text { 15. Non-Availability bridges } \\
\text { 16. Accessibility to major } \\
\text { intersections }\end{array}$ & $\begin{array}{l}\text { 1. Facility architectural } \\
\text { facade } \\
\text { 2. surrounding buildings } \\
\text { architectural facade } \\
\text { 3. Availability of enough } \\
\text { construction space } \\
\text { 4. construction materials } \\
\text { Quality } \\
\text { 5. finishing materials Quality } \\
\text { 6. High-rise Buildings } \\
\text { 7. commercial space } \\
\text { Availability in ground } \\
\text { floors } \\
\text { 8. building Modern age } \\
\text { 9. Diversity of activities in } \\
\text { the building } \\
\text { 10. Facility near to abandoned } \\
\text { buildings } \\
\text { 11. Building with dedicated } \\
\text { parking } \\
\text { 12. Proximity to high-rise } \\
\text { buildings } \\
\text { 13. Proximity to un- } \\
\text { constructed land space }\end{array}$ & $\begin{array}{l}\text { 1. High population density } \\
\text { Neighbourhoods } \\
\text { 2. The population } \\
\text { in neighbourhoods with th } \\
\text { e scattered spatial diffuse } \\
\text { distribution } \\
\text { 3. Population high } \\
\text { educational level } \\
\text { 4. High economic level of } \\
\text { the population } \\
\text { 5. Population high social } \\
\text { level }\end{array}$ & $\begin{array}{l}\text { 1. Property Low rental value } \\
\text { 2. Low price of land } \\
\text { 3. The existence of similar } \\
\text { activities of } \\
\text { targeted commercial } \\
\text { activity } \\
\text { 4. Availability of space for } \\
\text { targeted commercial } \\
\text { activity } \\
\text { 5. Proximity to living place } \\
\text { 6. Proximity to commercial } \\
\text { city center } \\
\text { 7. Availability of various } \\
\text { facilities (water, electricity } \\
\text { 8. Main owner } \\
\text { Rental facilities } \\
\text { 9. Site Commercial nature }\end{array}$ & $\begin{array}{l}\text { 1. Structural plan } \\
\text { contribution. } \\
\text { 2. Commercial land use } \\
\text { regulations. } \\
\text { 3. Changes in commercial } \\
\text { land use mechanism } \\
\text { 4. Availability of commercial } \\
\text { lands } \\
\text { 5. Spatial planning } \\
\text { contribution } \\
\text { 6. Concerns of the } \\
\text { commercial land use } \\
\text { patterns on sustainable } \\
\text { urban development } \\
\text { 7. City strategic location } \\
\text { 8. City Commercial } \\
\text { attraction } \\
\text { 9. Commercial nature of the } \\
\text { city } \\
\text { 10. Function of Tourist city } \\
\text { 11. Government support } \\
\text { 12. Oil economic effect } \\
\text { 13. Cities attraction } \\
\text { 14. Land use rapid dynamism } \\
\text { and diversity } \\
\text { 15. Forces of Deterrence and } \\
\text { attraction. }\end{array}$ \\
\hline
\end{tabular}


The survey was carried out in February and April, 2012. Respondents were approached between 9:00 a.m. and 3:00 p.m. for business owners and decision makers in order to meet them during the working hours. The survey was conducted by selecting different services commercial activities in six major commercial strips within Alkhobar city. Figure 2 shows the spatial location of the commercial strips which contain Prince Turki Bin AbdulAziz Road, King Fahd Bin AbdulAziz Road, Prince Homud Bin AbdulAziz Street, King Abdullah Bin AbdulAziz Road, Khaled Bin AlWaleed and Makkah Streets. The total number of questionnaires distributed in Alkhobar City survey was 120. 17 questionnaires were not returned or returned with incomplete responses. The total number of valid respondents was 103. Table 4 shows the number of respondents based on spatial location

\section{Table 4.}

Respondents based on spatial location

\begin{tabular}{clc}
\hline \hline $\begin{array}{c}\text { Survey } \\
\text { Method }\end{array}$ & \multicolumn{1}{c}{ City of residence } & \% of Respondents \\
\hline \multirow{2}{*}{} & King Fahd Ben Abdulaziz Rd. & 19.52 \\
$\frac{0}{0}$ & King Abdullah Ben Abdulaziz Rd. & 18.47 \\
& Prince Turkey Ben Abdulaziz St. & 27.17 \\
$\frac{0}{0}$ & Makkah St. & 9.76 \\
$\frac{0}{0}$ & Prince Homud Ben Abdulaziz St. & 12.54 \\
Khaled Bin Alwaleed St. & 12.54 \\
\hline
\end{tabular}

Before transmitting the variables collected for this study to the Statistical Package for Social Science (SPSS) program and initiation of target analysis, a number of requirements were fulfilled based on Stevens (1986):

1. Variables were converted in the initial matrix to percentages in order to unite all the variables in percentage unit.

2. All variables were converted from percentages to logarithmic values in order to ensure the moderate distribution of data and avoid the extremely very small values when compared with the higher.

3. All variables have been converted to standardized scores as required by Principle Component Analysis in order to establish uniform data.

Through SPSS, descriptive analysis was applied on all data gathered. The researcher calculated the range, minimum, maximum, mean, standard deviation, variance and data skewness factor to ensure the moderation distribution of data between $( \pm 3)$. Alpha coefficient computed from the data of this study was 0.916 , which indicates a high level of internal consistency for the scale with the study sample.

\subsection{Regression analysis}

A stepwise regression was implemented to define the most appropriate fit model that explains the factors affecting service-related commercial land use pattern in Alkhobar City by considering the respondents answers as Independent Variables and the parentage of annual increase of service-related commercial license number as Dependent Variable.

Journal of Engineering Sciences, Assiut University, Faculty of Engineering, Vol. 41, No. 3, pp. 1328 - 1351, May, 2013, E-mail address: jes@aun.edu.eg 


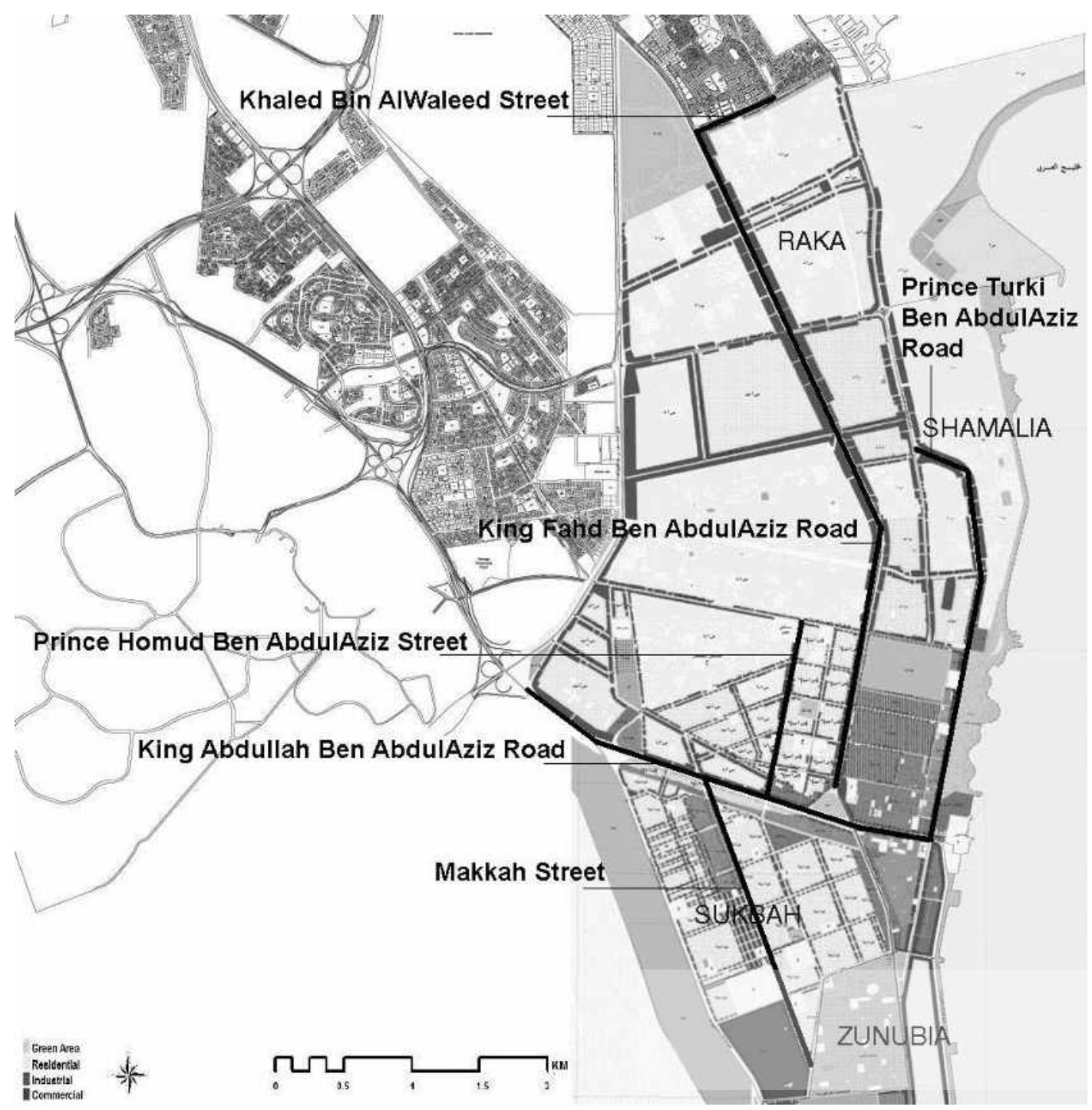

Fig. 3. Spatial Locations of the Targeted Commercial Strips

The model summary of the stepwise regression analysis results for the entire sample, representing the most appropriate fit model is presented in Table 5. The multiple regression coefficient in the model as a whole amounted to about (0.974), and the adjusted $\mathrm{R}$ square equals (0.954). In other words, it can be said that the produced variables under this model explain the factors affected service-related Commercial land use in Alkhobar City by (95.4\%).

Journal of Engineering Sciences, Assiut University, Faculty of Engineering, Vol. 41, No. 3, pp. 1328 - 1351, May, 2013,E-mail address: jes@aun.edu.eg 
M. A. Abdellatif, et al., Experts' optinions of factore affecting service-related commerical land use pattern: the case of Alkhobar city

\section{Table 5.}

Commercial Land Use Affection Factors Stepwise Regression Model Summary in Alkhobar City

\begin{tabular}{ccccccc}
\hline \hline Model & R & R Square & $\begin{array}{c}\text { Adjusted R } \\
\text { Square }\end{array}$ & $\begin{array}{c}\text { Std. Error of the } \\
\text { Estimate }\end{array}$ & F & Significance \\
\hline 1 & 0.775 & 0.600 & 0.550 & 0.01535283 & 11.997 & 0.009 \\
2 & 0.905 & 0.819 & 0.768 & 0.01103419 & 15.857 & 0.003 \\
3 & 0.962 & 0.925 & 0.887 & 0.00769607 & 24.527 & 0.001 \\
4 & 0.987 & 0.974 & $\mathbf{0 . 9 5 4}$ & 0.00490574 & 47.714 & 0.000 \\
\hline \hline
\end{tabular}

Table 6 contains the values of the regression coefficients and independent variables that explained the factors affecting service-related commercial land use in Alkhobar city, and their directions. The most effective variable in the regression model is the Availability of infrastructure facilities which represents site spatial planning characteristics. This variable affects service-related commercial land use in Alkhobar City by (55.0\%). The standardized regression coefficient $(\beta)$ value is an indicator of how strongly the independent variable influences the dependent variable and is measured in units of standard deviation. In this model beta value for the first factor is $(\beta=-0.964)$ which indicates that a change of standard deviation in factor 1 units will result in a change of $(-0.53)$ standard deviations in the parentage of yearly increasing of service-related commercial license number.

\section{Table 6.}

Results of the Stepwise Regression Analysis in Alkhobar City

\begin{tabular}{|c|c|c|c|c|c|c|c|}
\hline & \multirow{2}{*}{ Model } & \multicolumn{2}{|c|}{ Unstand. Coeff. } & \multirow{2}{*}{$\begin{array}{c}\begin{array}{c}\text { Stand. } \\
\text { Coeff. }\end{array} \\
\beta\end{array}$} & \multirow{2}{*}{$\begin{array}{l}\text { Adjusted } \\
\text { R Square }\end{array}$} & \multirow{2}{*}{$\mathbf{t}$} & \multirow{2}{*}{ Sig. } \\
\hline & & $\mathbf{B}$ & $\begin{array}{c}\text { Std. } \\
\text { Error }\end{array}$ & & & & \\
\hline \multirow{3}{*}{1} & (Constant) & 0.150 & 0.015 & & & 9.799 & 0.000 \\
\hline & Availability of infrastructure facilities & -0.028 & 0.008 & -0.775 & 0.550 & -3.464 & 0.009 \\
\hline & (Constant) & 0.134 & 0.012 & & & 10.768 & 0.000 \\
\hline \multirow[t]{3}{*}{2} & Availability of infrastructure facilities & -0.027 & 0.006 & -0.758 & 0.550 & -4.710 & 0.002 \\
\hline & High Neighborhoods population density & 0.011 & 0.004 & 0.469 & 0.768 & 2.913 & 0.023 \\
\hline & (Constant) & 0.173 & 0.016 & & & 10.710 & 0.000 \\
\hline \multirow{5}{*}{3} & Availability of infrastructu & -0.035 & 0.005 & -0.959 & 0.550 & -7.265 & 0.000 \\
\hline & High Neighborhoods population density & 0.011 & 0.003 & 0.461 & 0.768 & 4.111 & 0.006 \\
\hline & Spatial diffuse distribution neighborhoods & -0.013 & 0.005 & -0.382 & 0.887 & -2.896 & 0.027 \\
\hline & (Constant) & 0.168 & 0.010 & & & 16.009 & 0.000 \\
\hline & Availability of i & -0.035 & 0.003 & -0.964 & 0.550 & -11.451 & 0.000 \\
\hline \multirow[t]{3}{*}{4} & High Neighborhoods population density & 0.013 & 0.002 & 0.563 & 0.768 & 7.164 & 0.001 \\
\hline & Spatial diffuse distribution neighborhoods & -0.020 & 0.004 & -0.586 & 0.887 & -5.506 & 0.003 \\
\hline & Location near to major intersections & 0.009 & 0.003 & 0.317 & 0.954 & 3.125 & 0.026 \\
\hline
\end{tabular}

Journal of Engineering Sciences, Assiut University, Faculty of Engineering, Vol. 41, No. 3, pp. 1328 - 1351, May, 2013, E-mail address: jes@aun.edu.eg 
M. A. Abdellatif, et al., Experts' optinions of factore affecting service-related commerical land use pattern: the case of Alkhobar city

\subsection{Factor analysis}

Conducting Factor Analysis generated one factor related to site spatial planning characteristics and another one related to regulations and strategic issues. Table 7 shows that the characteristics related to building architecture, socio-economic issues and land ownership did not generate any factor that measured by at least three variables having communalities greater than 0.5 which result unsatisfactory solution that does not meet the minimum analysis requirements.

\section{Table 7.}

\section{Factors Communalities}

\begin{tabular}{llc}
\hline \multicolumn{1}{c}{ Factor } & \multicolumn{1}{c}{ Variables } & Communalities \\
\hline Site Spatial Planning & Availability of landscaping elements in site & $\mathbf{0 . 5 2 5}$ \\
& Road width & $\mathbf{0 . 5 3 1}$ \\
& Accessibility & $\mathbf{0 . 6 6 1}$ \\
& Mobility & $\mathbf{0 . 6 1 8}$ \\
Building & Construction materials quality & 0.761 \\
Architectural Design & Finishing materials quality & 0.801 \\
& Proximity to high-rise buildings & 0.132 \\
Socio-Economic and & Population high educational level & 0.679 \\
Demography & Population high economic level & 0.394 \\
& Ser-high social level of the population & 0.727 \\
Land values and & Low rental value of the property & 0.675 \\
Ownership & Ser-low price of land in the case of owning the property & 0.733 \\
& Ser-availability of adequate space for your commercial & 0.435 \\
Planning, & activity & \\
Regulations and & Commercial land use regulations (zoning, land & $\mathbf{0 . 5 8 7}$ \\
Economic Policies & distribution, etc.) Contributed in attracting city & \\
& commercial uses. & \\
& Mechanism changes in commercial land development & $\mathbf{0 . 6 7 4}$ \\
& contributed in attracting business activities. & \\
& Availability of commercial lands to population & $\mathbf{0 . 5 5 8}$ \\
\hline \hline
\end{tabular}

The factor related to site spatial planning characteristics derived $58.36 \%$ combined interpreted of the variance in the original variables considered. Table 8 shows the Total Variance Explained indicating that only one factor was generated and that is considered as the most important one by default.

\section{Table 8.}

Site Spatial Planning Variables (Total Variance Explained) in Alkhobar City

\begin{tabular}{ccccccc}
\hline \hline \multirow{2}{*}{ Component } & \multicolumn{3}{c}{ Initial Eigenvalues } & \multicolumn{3}{c}{ Rotation Sums of Squared Loadings } \\
& Total & \% of Variance & Cumulative \% & Total & $\%$ of Variance & Cumulative \% \\
\hline 1 & 2.335 & 58.365 & 58.365 & 2.335 & 58.365 & $\mathbf{5 8 . 3 6 5}$ \\
\hline \hline
\end{tabular}

Journal of Engineering Sciences, Assiut University, Faculty of Engineering, Vol. 41, No. 3, pp. 1328 - 1351, May, 2013, E-mail address: jes@aun.edu.eg 
M. A. Abdellatif, et al., Experts' optinions of factore affecting service-related commerical land use pattern: the case of Alkhobar city

Table 9 shows the Component Matrix and concentration of Component Scores for site spatial planning variables by using Factor Analysis as Extraction Method, Varimax with Kaiser Normalization as Rotation Method.

Table 9.

Site Spatial Planning Variables (Component and Score Coefficient Matrix) in Alkhobar City

\begin{tabular}{lcc}
\hline \hline \multicolumn{1}{c}{ Variables } & $\begin{array}{c}\text { Component } \\
\text { matrix }\end{array}$ & $\begin{array}{c}\text { Concentration of } \\
\text { component scores }\end{array}$ \\
\hline Availability of landscaping elements in site & 0.724 & 0.310 \\
Road width & 0.729 & 0.312 \\
Accessibility & 0.813 & 0.348 \\
Mobility & 0.786 & 0.337 \\
\hline \hline
\end{tabular}

The factor related to regulations and strategic issues derived $60.63 \%$ combined interpreted of the variance in the original variables which were considered. Table 10 shows Total Variance Explained indicating that only one factor was generated in this category and was considered the most important one by default.

Table 10.

Regulations and Strategic Variables (Total Variance Explained) in Alkhobar City

\begin{tabular}{ccccccc}
\hline \hline \multirow{2}{*}{ Component } & \multicolumn{3}{c}{ Initial Eigenvalues } & \multicolumn{3}{c}{ Rotation Sums of Squared Loadings } \\
& Total & \% of Variance & Cumulative \% & Total & $\%$ of Variance & Cumulative \% \\
\hline 1 & 1.819 & 60.633 & 60.633 & 1.819 & 60.633 & $\mathbf{6 0 . 6 3 3}$ \\
\hline \hline
\end{tabular}

Table 11 shows Component Matrix and concentration of Component Scores for Planning, Regulations and Economic Policies variables by using Factor Analysis as Extraction Method, Varimax with Kaiser Normalization as Rotation Method.

\section{Table 11.}

Regulations and Economic Policies variables (Component and Score Coefficient Matrix) in Alkhobar City

\begin{tabular}{lcc}
\hline \hline \multicolumn{1}{c}{ Variables } & $\begin{array}{c}\text { Component } \\
\text { matrix }\end{array}$ & $\begin{array}{c}\text { Concentration of } \\
\text { component scores }\end{array}$ \\
\hline $\begin{array}{l}\text { Commercial land use regulations (zoning, land distribution, } \\
\text { etc.) contributed in attracting city commercial uses. }\end{array}$ & 0.766 & 0.421 \\
$\begin{array}{l}\text { Mechanism changes in commercial land development } \\
\text { contributed in attracting business activities. }\end{array}$ & 0.821 & 0.451 \\
$\begin{array}{l}\text { Availability of commercial lands to population contributed } \\
\text { to commercial activities attraction. }\end{array}$ & 0.747 & 0.411 \\
\hline
\end{tabular}

\subsection{Analysis summary}

Regression Analysis and Factor Analysis derived the factors affecting service-related commercial land use pattern in Alkhobar City and described in Figure 3.

Journal of Engineering Sciences, Assiut University, Faculty of Engineering, Vol. 41, No. 3, pp. 1328 - 1351, May, 2013, E-mail address: jes@aun.edu.eg 


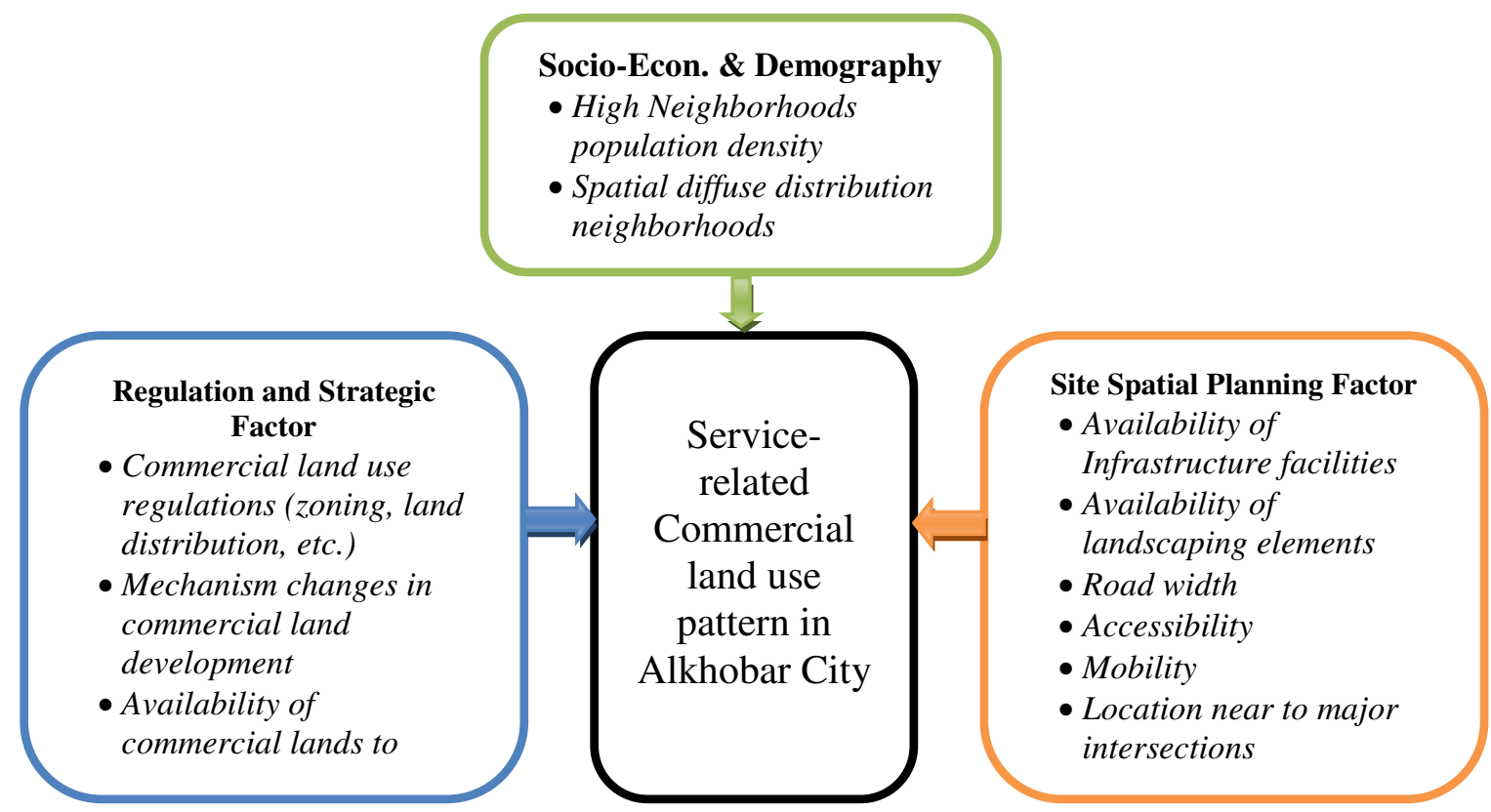

Fig. 3. Factors Affecting Service-related Commercial Land Use Pattern in Alkhobar City

\subsection{Testing Research Hypothesis}

The purpose of hypothesis testing is to determine whether there is enough statistical evidence in favour of a certain belief, or hypothesis, about a parameter. Table 12 shows the study hypothesis testing result which indicates that study hypothesis was rejected and replaced by the null-hypothesis.

Table 12.

Study Hypothesis Testing Result

\begin{tabular}{|c|c|c|c|}
\hline $\mathrm{Sr}$ & Hypothesis (H1) & Null-Hypothesis (H0) & Study Decision \\
\hline 1 & $\begin{array}{l}\text { There is no statistically significant } \\
\text { relationship between services } \\
\text { commercial lands use pattern and } \\
\text { the spatial planning of the site, } \\
\text { architectural design of the } \\
\text { building, } \\
\text { population demographic and } \\
\text { economic characteristics, relation } \\
\text { with landlords and business } \\
\text { owners and factors related } \\
\text { to planning and regulations } \\
\text { and strategic planning. }\end{array}$ & $\begin{array}{l}\text { There is statistically significant } \\
\text { relationship between services } \\
\text { commercial lands uses pattern and } \\
\text { the spatial planning of the site, } \\
\text { architectural design of the } \\
\text { building, } \\
\text { population demographic and } \\
\text { economic characteristics, relation } \\
\text { with landlords and business } \\
\text { owners and factors related } \\
\text { to planning and regulations } \\
\text { and strategic planning. }\end{array}$ & $\begin{array}{l}\text { The results of } \\
\text { Regression and } \\
\text { Factor Analysis } \\
\text { indicate that there } \\
\text { are statistically } \\
\text { significant } \\
\text { relationships. } \\
\text { Therefore, the } \\
\text { study concludes to } \\
\text { reject the H1 } \\
\text { hypothesis. }\end{array}$ \\
\hline
\end{tabular}

Journal of Engineering Sciences, Assiut University, Faculty of Engineering, Vol. 41, No. 3, pp. 1328 - 1351, May, 2013, E-mail address: jes@aun.edu.eg 
M. A. Abdellatif, et al., Experts' optinions of factore affecting service-related commerical land use pattern: the case of Alkhobar city

\section{Conclusion and Recommendations}

The study findings provide proper explanation of the research problem through testing the hypothesis. The study encourages further studies on land use issues in Saudi Arabia. It builds a sound understanding of the factors affecting service-related commercial land use pattern. It provides proper ways to urban land use planning in Saudi Arabia in general and in Alkhobar City in specific.

The results of the study indicated that there are factors affecting service-related commercial land use pattern in Alkhobar City. These factors are related to the site spatial planning directly. The site spatial planning parameters included road width, availability of landscape elements, accessibility and mobility.

Some of variables listed under these factors can be controlled and steered for better commercial land use planning. Others like land value is difficult to be controlled because it is based on demand and supply strategy and not deemed feasible to alter or control.

The study recommends that further analyses and investigation on these interrelationships shown take place by researchers. Also, developing proper guidelines to control land use pattern are needed to allow for the retention and expansion of development in the established areas of the city.

\section{References}

[1] Al-Kahtani, S. H. (2011). Optimal Groundwater Irrigation Allocation of Al-Wajid Aquifer in the Kingdom of Saudi Arabia. Journal of Agricultural Science \& Technology B, 735-745.

[2] Al-Saud, M. I. (2010). Evaluation of Potential Impacts of Agricultural Policy Reforms on Sustainability of Groundwater Resources of Saudi Arabia. Journal of Agricultural Science \& Technology (19391250), 4(5), 112-120.

[3] Al-Shihri, Faez and Benson, John. The National-Local Policy Vacuum in Sustainable Land-use Planning: Al-Qatif Oasis, Saudi Arabia. Oxford: EOLSS Publishers, 2002. Print.

[4] Alshuwaikhat, H. M., \& Aina, Y. A. (2006). GIS-based urban sustainability assessment: The case of Dammam city, Saudi Arabia. Local Environment, 11(2), 141-162. doi:10.1080/13549830600558432

[5] Al-Sudairi, A. A., \& Al-Motairi, M. S. (2010). Multi objective land use allocation model using priority-based goal programming technique. Construction Management \& Economics, 28(2), 151161. doi:10.1080/01446190903460698

[6] Am J Prev Med 2005; 28(2S2):186 -193, American Journal of Preventive Medicine

[7] Asharqia Chamber (2011) List of Eastern Region Commercial License Members, Dammam, Saudi Arabia.

[8] Barnett, Jonathan (1982), An Introduction to Urban Design, Harper \& Row, New York.

[9] Berke,P., Godschalk, D., Kaiser, E., Rodríguez, D. (2006). Urban Land Use Planning, 5th Edition,. University of Illinois Press, Chicago.

[10] Bourassa, S.C., M. Hoesli and J. Sun, "What's in a View," Environment and Planning A, 36, $1427-$ 1450 (2004).

[11] Dammam Municipality (2006) Urban and Regional Planning Department, Dammam, Saudi Arabia.

[12] Dammam Municipality (2007) Urban and Regional Planning Department, Dammam, Saudi Arabia.

[13] Friedman, John, and Hudson, Barclay. (2005). Knowledge and action: a guide to planning theory. Journal of the American Institute of Planners 40, 1:3-16.

[14] Friedman, John. (2006). Retracking America. A theory of transactive planning. Garden City, N.Y.: Doubleday-Anchor.

[15] Hough, D. E. \& Kratz, C. G. (1983) Can “Good” Architecture Meet the MarketTest?. Journal of Urban Economics, 14,40 - 54.

[16] Johnson, J.H. (1972) Urban Geography: An Introductory Analysis, Second Edition (Pergamon Press, Oxford). p. 130.

Journal of Engineering Sciences, Assiut University, Faculty of Engineering, Vol. 41, No. 3, pp. 1328 - 1351, May, 2013,E-mail address: jes@aun.edu.eg 
M. A. Abdellatif, et al., Experts' optinions of factore affecting service-related commerical land use pattern: the case of Alkhobar city

[17] Lane, J.S. and K.D. Vandell, "The Economics of Architecture and Urban Design: Some Preliminary Findings," AREUEA Journal, 17:2, 235-260 (1989).

[18] Mustapha, M. R., Lim, H. S., Hassan, F. M., \& Jafri, M. (2010). Evaluation of Land Cover Features over Jeddah, Saudi Arabia Using ALOS AVNIR-2 Sensor. AIP Conference Proceedings, 1250(1), 173-176. doi:10.1063/1.3469628.

[19] Quest Economics Database, (2008) "Middle East Review World of Information, Saudi Arabia." Country Profile October.

[20] Small, R. J., and Witherick, M., 1986. A Modern Dictionary of Geography (London: Edward Arnold). Kni Ref. G63.S53 1986

[21] Stevens, J. (1986). Applied multivariate statistics for the social sciences. Hillsdale, NJ: Lawrence Erlbaum Associates.

\title{
7. Appendix
}

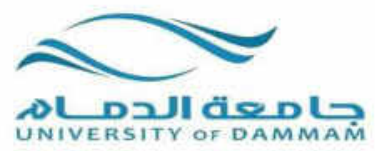

Kingdom of Saudi Arabia

University of Dammam

Architectural and Planning College

Urban and Regional Planning

\section{Questionnaire}

\author{
Study Subject \\ Experts' Opinions of Factors Affecting \\ Service-related Commercial Land Use Pattern: \\ the Case of Alkhobar City
}

Researcher

Bandar A. Al-Nuaim

\begin{tabular}{|c|c|}
\hline $\begin{array}{r}\text { Questionnaire } \\
\text { No. }\end{array}$ & \\
\hline Date & $/ \ldots \ldots / 1433 \mathrm{AH}$ \\
\hline Duration & A..................... Minutes \\
\hline $\begin{array}{r}\text { Conmercial } \\
\text { Name }\end{array}$ & \\
\hline $\begin{array}{r}\text { Type } \\
\text { Profession }\end{array}$ & Others $\square$ Comity $\square$ Private $\square$ Governmental \\
\hline $\begin{array}{r}\text { Years of } \\
\text { Experience }\end{array}$ & \\
\hline Age & \\
\hline Sex & \\
\hline
\end{tabular}

$1433 \mathrm{AH} / 2012 \mathrm{AD}$

Journal of Engineering Sciences, Assiut University, Faculty of Engineering, Vol. 41, No. 3, pp. 1328 - 1351, May, 2013,E-mail address: jes@aun.edu.eg 
Dear Honorable,

Assalamu Alikum, Peace \& blessing of god to you...

This Questionnaire is a part of PhD Study in Urban \& Regional Planning; it aims into studying the effect of various factors on the commercial land use in Saudi Arabia generally and specific in Al-Khobar City. (Attracting or Deterrence). The target questionnaire population is leaders, owners, Investors and many decision makers of various Foundations in $\mathrm{Al}-$ Khobar City.

The questions generally focus on the Site, demographic, Economic \& Social Characteristics of Al- Khobar City and many other preferences to the Businessmen, Leaders and Decision makers.

The results of this study will provide some insights and information on how to find a way to conserve the proper urban land use planning in Saudi cities.

The questionnaire designed to be completed by professionals is 10 minutes.

Thank you for cooperation and be assured that the collected data will be used for research related only.

Please send the application after completion to any of the following: p.o box: 2027 Dammam 31451

Fax number: 038099736

Email: nbander@gmail.com

Your cooperation on this regard is highly appreciated.

Researcher 


\section{Definitions:}

\section{Services Commercial Uses:}

Services Commercial activities based on commercial license which will reflect the existing distribution of commercial uses within Saudi Arabia. Classification contains:

A. Service commercial activities (sales-related to services) like insurance services and warranty, real estate offices, transport of passengers and goods services, Transportation Services, agricultural services, services relating to trade, services of banks and financial institutions.

\section{Variables affect attraction or deterrence of commercial uses: \\ Intended parameters that would increase the degree of attracting or repellent commercial use of the site, which can be summarized by several factors like spatial planning, design, and demographic factors.}


M. A. Abdellatif, et al., Experts' optinions of factore affecting service-related commerical land use pattern: the case of Alkhobar city

Q1. In your opening what are the effects of all listed factors on the commercial land use?

1. Factors related to the Characteristics of the spatial planning of the site

\begin{tabular}{|c|c|c|c|c|c|c|}
\hline & \multirow[t]{2}{*}{ Factors Affecting } & \multicolumn{5}{|c|}{$\begin{array}{l}\text { Service commercial activities (sales- } \\
\text { related services) }\end{array}$} \\
\hline & & \begin{tabular}{|l} 
Migh \\
Atrenat \\
\end{tabular} & $\begin{array}{l}\text { Medium } \\
\text { Atract }\end{array}$ & \begin{tabular}{|l} 
No \\
Relation \\
\end{tabular} & \begin{tabular}{|l|l|} 
Renativinty \\
Deterrena \\
\end{tabular} & 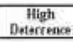 \\
\hline 1.1 & Grid planning & & & & & \\
\hline 1.2 & Horizontal proliferation & & & & & \\
\hline 1.3 & Avallability of infrastructure facilities & & & & & \\
\hline 1.4 & Outskirts site on the city & & & & & \\
\hline 1.5 & Site in the city center & & & & & \\
\hline 1.6 & $\begin{array}{l}\text { Avallability of Urban Spaces in the } \\
\text { surrounding area }\end{array}$ & & & & & \\
\hline 1.7 & Availability of green spaces & & & & & \\
\hline 1.8 & Availability of landscaping elements & & & & & \\
\hline 1.9 & Road width & & & & & \\
\hline 1.10 & Quick access to the site (Accessibility) & & & & & \\
\hline 1.11 & $\begin{array}{l}\text { Smooth flow of traffic on the roads around the } \\
\text { site (Mobility) }\end{array}$ & & & & & \\
\hline 1.12 & Wide sidewalks & & & & & \\
\hline 1.13 & Availability of car parking & & & & & \\
\hline 1.14 & Away from site tuninels & & & & & \\
\hline 1.15 & Away from of bridges & & & & & \\
\hline 1.16 & Near to major intersections & & & & & \\
\hline
\end{tabular}

2. Factors related to the Characteristics of Architectural design of the building

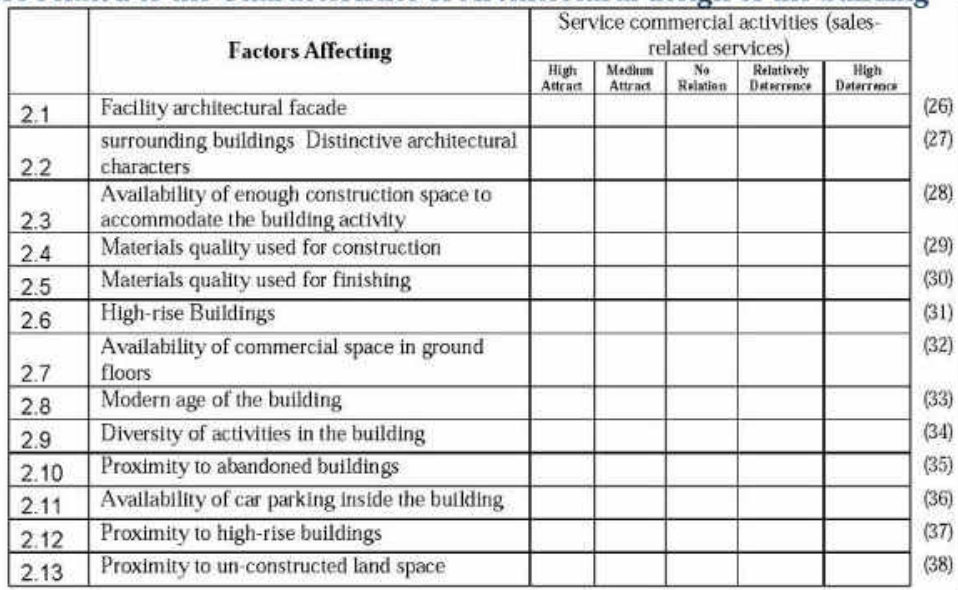

3. Factors related to the Characteristics of Population demographic and economic

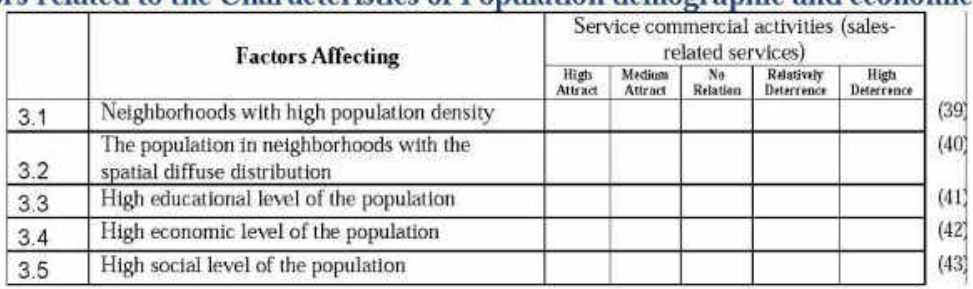

Journal of Engineering Sciences, Assiut University, Faculty of Engineering, Vol. 41, No. 3, pp. 1328 - 1351, May, 2013,E-mail address: jes@aun.edu.eg 
4. Factors related to the Characteristics of owners, landlords and business owners By suggestion that you are one of the owners of commercial activities

\begin{tabular}{|c|c|c|c|c|c|c|}
\hline & \multirow{2}{*}{ Factors Affecting } & \multicolumn{5}{|c|}{$\begin{array}{l}\text { Service commercial activities (sales- } \\
\text { related services) }\end{array}$} \\
\hline & & $\begin{array}{c}\text { High } \\
\text { Altrad }\end{array}$ & $\begin{array}{l}\text { Medium } \\
\text { Attrad }\end{array}$ & 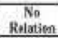 & $\begin{array}{l}\text { Relativivy } \\
\text { Detercenat }\end{array}$ & $\begin{array}{c}\text { High } \\
\text { Detersence }\end{array}$ \\
\hline 4.1 & Low rental value of the property & & & & & \\
\hline 4.2 & $\begin{array}{l}\text { Low price of land in the case } \\
\text { of owning the property }\end{array}$ & & & & & \\
\hline 4.3 & The existence of similar activities & & & & & \\
\hline 4.4 & Availability of adequate space & & & & & \\
\hline 4.5 & Proximity to your owner house & & & & & \\
\hline 4.6 & Proximity to commercial city center & & & & & \\
\hline 4.7 & $\begin{array}{l}\text { Avadlability of various } \\
\text { facilities (water, electricity, sanitation, } \\
\text { etc.) }\end{array}$ & & & & & \\
\hline 4.8 & Rental facilities by the main owner & & & & & \\
\hline 4.9 & Commercial nature of the site & & & & & \\
\hline
\end{tabular}

5. Factors related to planning, economic and strategic issues

\begin{tabular}{|c|c|c|c|c|c|c|}
\hline & \multirow[b]{2}{*}{ Factors Affecting } & \multicolumn{5}{|c|}{ Rating } \\
\hline & & $\begin{array}{c}\text { High } \\
\text { Agree }\end{array}$ & Agree & Neutral & Disagree & $\begin{array}{c}\text { High } \\
\text { Disagree }\end{array}$ \\
\hline 5.1 & $\begin{array}{l}\text { A comprebensive structural plan contributed to attract } \\
\text { commerctal uses of the city. }\end{array}$ & & & & & \\
\hline 5.2 & $\begin{array}{l}\text { Commercial land use regulations (zoning, land distribution, } \\
\text { etc.) have contributed to attract commercial uses of the city. }\end{array}$ & & & & & \\
\hline 5.3 & $\begin{array}{l}\text { Significant changes in the mechanism for the development } \\
\text { of commercial land contributed in attracting business } \\
\text { activities. }\end{array}$ & & & & & \\
\hline 5.4 & $\begin{array}{l}\text { Alteration of Residential Lands into Mixed use } \\
\text { (CommercialtResidential) contributed to the attraction of } \\
\text { commercial activities. }\end{array}$ & & & & & \\
\hline 5.5 & $\begin{array}{l}\text { Spatial planning helped in reducing the impact of random } \\
\text { "unplanned" growth of the commercial land uses }\end{array}$ & & & & & \\
\hline 5.6 & $\begin{array}{l}\text { There are grave concerns of the commercial land use pattern } \\
\text { growing on sustainable urban development of Al- Khobar } \\
\text { City }\end{array}$ & & & & & \\
\hline 5.7 & $\begin{array}{l}\text { The strategic location of the city contributes in increasing } \\
\text { the area of commercial use }\end{array}$ & & & & & \\
\hline 5.8 & $\begin{array}{l}\text { Commercial nature of the city led to the influx of large } \\
\text { numbers of consumers from different regions }\end{array}$ & & & & & \\
\hline 5.9 & $\begin{array}{l}\text { Commerclal nature of the city contributed to increase the } \\
\text { area of commerclal uses }\end{array}$ & & & & & \\
\hline 5.10 & $\begin{array}{l}\text { Tourism has affected the increase of commercial uses area } \\
\text { significantly. }\end{array}$ & & & & & \\
\hline 5.11 & $\begin{array}{l}\text { The development encouragement has increased the } \\
\text { proportion of commercial uses in the city. }\end{array}$ & & & & & \\
\hline 5.12 & $\begin{array}{l}\text { Oil led economic boom experienced by the Saudi cities } \\
\text { attract business activities intensively to al-Khobar } \mathrm{City}\end{array}$ & & & & & \\
\hline 5.13 & $\begin{array}{l}\text { It is noted that commercial use is growing in the attractive } \\
\text { characteristics cittes }\end{array}$ & & & & & \\
\hline 5.14 & $\begin{array}{l}\text { It is noted that the uses of Saudi urban land characterized by } \\
\text { rapid dynamism and diversity }\end{array}$ & & & & & \\
\hline 5.15 & $\begin{array}{l}\text { The forces of Deterrence and attraction have arranged the } \\
\text { uses in the heart of the city }\end{array}$ & & & & & \\
\hline
\end{tabular}

Journal of Engineering Sciences, Assiut University, Faculty of Engineering, Vol. 41, No. 3, pp. 1328 - 1351, May, 2013, E-mail address: jes@aun.edu.eg 
استطلاع آراء الخبراء عن العوامل المؤثرة في نمط الاستخدام التجاري الخدمي: دراسة حالة مدينة الخبر فئر الأن

\section{ملخص}

نظر اللنص الملحوظ في البحوث العلمية المحلية بالمملكة العربية السعودية التي تبحث في المواضيع

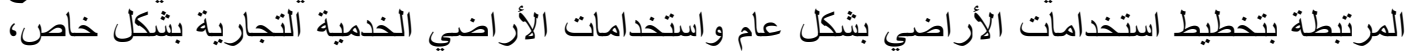

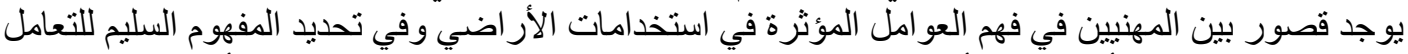

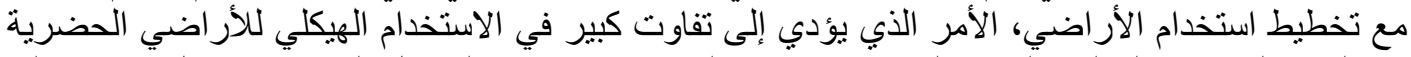

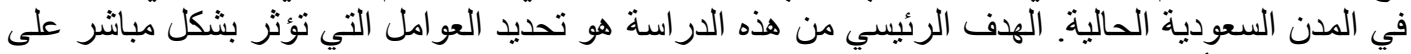

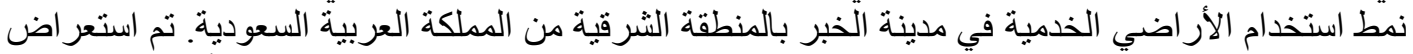
الدر اسات السابقة بشكل موسع للتمكن من تحديد العوامل التي تؤثر على فئ نمط استخدام الأر اضي الخدي الخدمية

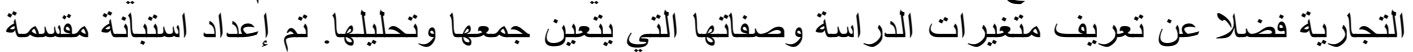

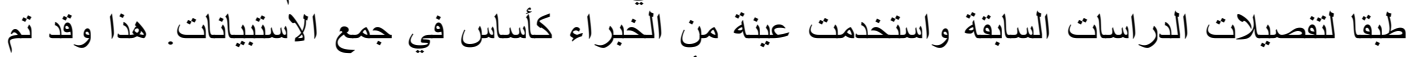

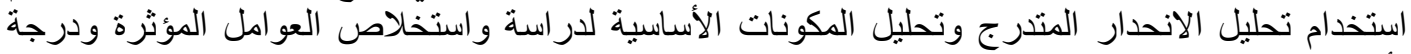

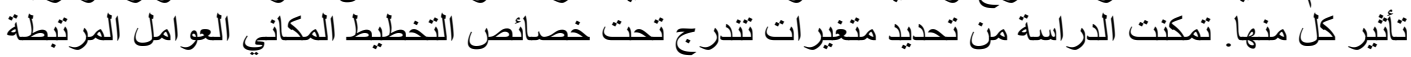

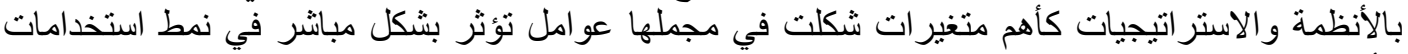

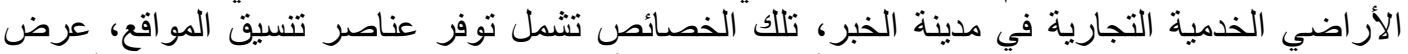

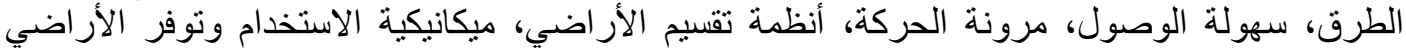

لاستخدام السكان.

كلمات مفتاحية

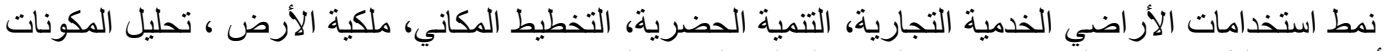
الأساسية، تحليل الانحدار المتدرج، مدينة الخبر ، المملكة العربية السعبة التعودية.

Journal of Engineering Sciences, Assiut University, Faculty of Engineering, Vol. 41, No. 3, pp. 1328 - 1351, May, 2013,E-mail address: jes@aun.edu.eg 